\title{
Definindo nação e Estado: rituais cívicos na Bahia pós-Independência (1823-1850)
}

\section{Hendrik Kraay}

$\mathrm{A}_{\text {vembro de } 1835 .{ }^{2} \text { Bernardo José, aparentemente enlouquecido, apu- }}^{\text {faí Barata de Almeida sofreu uma trádia na noite de } 8 \text { de no- }}$ nhalou e matou sua mãe, feriu seu pai e atacou os guardas que responderam aos gritos emanados da casa, localizada nos subúrbios de Salvador, Bahia. Um dos guardas traspassou Bernardo José com uma baioneta e o artesão surdo com 29 anos expirou gritando: "Viva a Bahia! Viva a liberdade! Morram os tiranos!" Segundo um outro relato, suas últimas palavras foram um pouco diferentes: "Viva a Pátria e morram os tiranos!" O Diário da Bahia lembrou que Bernardo José era sobrinho de Cipriano José Barata de Almeida, conhecido exaltado que, na época, candidatava-se a uma vaga no Senado, e atribuiu a morte à "educação perversa (...) que nos consta receber de seus pais esse celerado, a quem se atribuem os mais detestáveis vícios, e que os coroara com esse crime, que fez tremer a toda a Natureza".

Alguns dias depois, O Defensor do Povo publicou uma longa defesa do falecido Bernardo José. Reconhecendo que o jovem tinha um "gênio sombrio, e cismático," o jornal sustentou que ele todavia "amava extremosamente a liberdade, e muito se entretinha com as coisas que entendia fazer a bem da sua Pátria," pelas quais ele sofrera uma prisão injusta durante dois anos (1831-1833). A verdadeira causa do assassinato, segundo O Defensor, merece ser citada na íntegra:

Foi porque dias antes do dia 8 do corrente os marotos e os amorotados inimigos da glória dos Brasileiros, sabendo que os amigos da Pátria, reunidos no Campo de Pirajá, pretendiam celebrar o aniversário da glória deste DIA ganhada pelas armas Brasileiras no referido campo, propagaram boatos de uma nova rusga; outros aproveitaram-se da mesma ocasião, para fazerem crer que os mulatos, e negros cabras e crioulos, deveriáo ser deportados para 
uma Ilha do Brasil, a fim de não haver quem fizesse oposição à introdução de mais marotos no Brasil, a títulos de colonos; [e] para que, acabando-se com a raça dos mulatos e negros, apurassem a dos brancos.

Sabendo do trama:

O infeliz Bernardo José Barata de Almeida (...) ficou em extremo pensativo, e começou a cismar; tanto que no dia 7 , a sua conversação só era dizer, que "Será possível, que os marotos, acobertados com o manto da tirania, nos queirão lançar fora do nosso Pais, a fim de ficarem com a nossa terra!!"

No dia seguinte, estava "ao todo doido"; os pais o levaram para a casa, mas ele não os reconhecia. Acordou em alta noite e os atacou.

Enquanto a sanidade do cismativo Bernardo José deixava algo a desejar, a análise da tragédia feita por $O$ Defensor traz indícios da complexa política popular em torno das festas cívicas no Brasil pós-Independência. A data do caso, 8 de novembro de 1835, foi o décimo terceiro aniversário da grande vitória patriota sobre as forças portuguesas assediadas em Salvador, a Batalha do Pirajá. O dia nunca chegou a ser feriado oficial, mas há alguns indícios de comemorações realizadas no Pirajá, atualmente um subúrbio pobre de Salvador. Dois anos mais tarde, o vice-cônsul britânico informou que "o dia 8 deste mês é um grande feriado político nos arredores desta cidade e é antecipado com alguma ansiedade; é de esperar que passe tranqüilamente". ${ }^{3}$ Em 1850 , contudo, um jornal comentou que 8 de novembro, "uma das grandes épocas da independência," passara despercebido. $^{4}$

Os boatos que alegadamente fizeram enlouquecer o jovem Bernardo José destacam a lusofobia que caraterizava o patriotismo pós-Independência e sublinham a importância da raça na política desses anos. Muito dado ao patriotismo, ele aparentemente se identificava com os "mulatos, negros cabras, e crioulos" que seriam deportados do Brasil dos marotos brancos. Não há indício nenhum sobre o que fez Bernardo José crer no boato. É possível que as deportaçóes dos africanos suspeitos depois do levante dos Malês (ocorido há menos de um ano) fizessem parte das preocupações do jovem patriota, como sugere Marco Morel (2001, p. 306), mas elas eram restritas a africanos, e Bernardo José só falou da deportação de brasileiros. 
Deportaçôes faziam parte da experiência dos exaltados da época. Morel nos lembra que o pai de Bernardo, Raimundo José Barata de Almeida, fora deportado para uma ilha depois da Conspiração dos Alfaiates em 1798 (2001, p. 307) e que seu tio, Cipriano, passara muitos anos em prisões, inclusive no Forte do Mar, localizado numa pequena ilha no porto de Salvador. Em 1838, uns duzentos participantes da Sabinada seriam deportados sumariamente para Fernando de Noronha (KRAAY, 1992, pp. 521522). E, de fato, alguns estadistas brasileiros já criticavam o tráfico de escravos e propunham a imigração européia. Há uns dez anos atrás, o Marquês de Barbacena analisou a questão em termos raciais quando urgia a contratação de mercenários europeus para estimular o "cruzamento das raças": "homens altos, e claros" eram essenciais para que "os naturais do país não se reduzam a Anões cor de cobre." Ao identificar-se com mulatos e negros, Bernardo José fez parte da ainda pouco conhecida tendência de ver a nação recém-independente como composta dos seus membros não brancos, em vez de consistir somente da sua elite branca. ${ }^{6}$

Além de assumir uma identidade racial, Bernardo José declarou sua identidade política. Ao justapor os dois relatos das suas últimas palavras, se percebe que ele considerava a Bahia sua pátria, uma identificação com a antiga capitania colonial ou a nova província imperial comum entre brasileiros da época (BARMAN, 1988, pp. 26-28; LYRA, 1998). O Defensor, contudo, apresentou uma visão mais ampla da pátria, caraterizando 8 de novembro como o dia da glória brasileira e declarando que os "amigos da Pátria” comemoravam uma vitória brasileira, e não só uma baiana. Assim, o incidente destaca a tensão entre a lealdade à pátria local (Bahia) e o estado-nação (Brasil, que ainda não era, para muitos, uma pátria), uma tensão que permeava o patriotismo baiano oitocentista (KRAAY, 1999, pp. 275283).

Os relatos sobre a morte de Bernardo José oferecem um vislumbre raro e passageiro dos significados que um indivíduo ordinário atribuía à comemoração de um aspecto da luta pela independência na Bahia. A maioria das reportagens jornalísticas sobre tais festas — raramente se encontram relatos na documentação manuscrita - oferece poucos indícios sobre o significado das comemorações para os homens e mulheres que a elas assis- 
tiam ou delas participavam. É fácil analisar tais relatos como parte de um projeto que tentava inculcar lealdade ao estado e criar uma identidade brasileira, distinta da portuguesa de ambos os hemisférios (o fracassado projeto dos anos 1810 e início dos anos 1820) e, mais importante, maior do que a lealdade às pátrias locais. Neste sentido, festas cívicas colocavam problemas complexos de representação pública e questôes-chave sobre inclusão e exclusão da nação. Para abordar esses temas, este artigo analisa o projeto de festas cívicas nas primeiras três décadas depois da independência na Bahia, e principalmente na capital de Salvador, a segunda cidade do Brasil na época, focalizando os três principais feriados cívicos então comemorados: 2 de julho, 7 de setembro, e 2 de dezembro. As duas seções seguintes passam para uma análise da política da elite e da política popular nessas festas cívicas. Elas refletiam claramente a política da época, tanto na sua visão de uma sociedade hierárquica e ordeira quanto nas mudanças nas datas comemoradas. Como sugere o caso do infeliz Bernardo José, setores amplos da sociedade baiana participavam nas comemoraçóes que às vezes apresentavam também uma visão popular do estado-nação. Participando das festas, grupos populares tentavam demarcar seu lugar no espaço público e cívico, questionando a versão oficial da história da fundação da nação e do estado ou atribuindo-lhe novos sentidos.

\section{0 projeto das festas civicas}

Da época colonial, o Brasil herdou uma viva tradição de comemorar os aniversários, casamentos e Coroações dos monarcas e dos outros membros da família real com iluminações, Te-déuns, paradas militares, fogos de artifício e salvas de artilharia em festejos que têm sido ultimamente muito estudados (PRIORE, 1994; I. SOUZA, 1998, cap. 5; MALERBA, 2000, caps. 2-3; JANCSÓ e KANTOR, 2001). A criação de um novo Estado independente — um império, aliás — nos anos 1820 requeria novos "feriados nacionais." Em 1826, na primeira sessão do parlamento brasileiro, foram designados cinco feriados, quatro dos quais eram ligados diretamente ao Dom Pedro I: 1 de janeiro (a sua decisão de ficar no Brasil em 1822); 25 de março (o aniversário do juramento brasileiro de 1824 à Constituição outorgada pelo imperador que antes fechara a assembléia constituinte); 7 
de setembro (a data do Grito do Ipiranga de Dom Pedro — "Independência ou Morte"- em 1822, dia que aos poucos venceu as outras datas e virou feriado nacional brasileiro); 12 de outubro (dia da aclamação de Dom Pedro em 1822 e seu aniversário). O quinto feriado, 3 de maio (dia da abertura da primeira sessão do parlamento brasileiro em 1826), foi um aditamento de última hora pela câmara dos deputados aos quatro feriados francamente monárquicos aprovados pelo senado. Os deputados achavam que seu papel numa monarquia constitucional merecia uma comemoração. ${ }^{7}$ A abdicação do Dom Pedro em 1831 obrigou a regência a revisar a lista dos feriados. Em outubro de 1831, um decreto eliminou o 12 de outubro (a aclamação de Dom Pedro I), acrescendo 2 de dezembro (o aniversário do jovem Dom Pedro II) e 7 de abril (a abdicação de Dom Pedro I). Este foi delicadamente descrito como a comemoração da "Devolução da Coroa ao Sr. Dom Pedro." Afinal de contas, nenhuma monarquia — nem a regência liberal — podia publicamente celebrar a abdicação a qual foi obrigado o imperador. Um mês depois da aclamação da maioridade de Dom Pedro II no dia 23 de Julho de 1840, o governo acrescentou o dia aos outros feriados cívicos. Enfim, em 1848, o número de feriados nacionais foi reduzido a três: 25 de março, 7 de setembro e 2 de dezembro. ${ }^{8}$

$\mathrm{Na}$ Bahia, os feriados adotados em 1826 não tinham o mesmo significado que tinham no Rio de Janeiro. Além de 8 de novembro, mais três datas concorriam a feriados nacionais na província. Na Ilha de Itaparica (do outro lado da Bahia, frente a Salvador), patriotas comemoravam o dia 7 de janeiro em homenagem à derrota de uma tentativa de desembarque portuguesa em 1823. Na segunda cidade da província, Cachoeira, palco do governo patriota em 1822 e 1823, comemorava-se 25 de junho, o dia em que sua câmara municipal aclamou Pedro I como defensor perpétuo do Brasil em 1822, um passo-chave que ligou a causa patriota baiana ao Rio de Janeiro, onde o monarca estava em caminho à ruptura final com Lisboa. Finalmente, na cidade de Salvador, comemorava-se a evacuação das tropas portuguesas no dia 2 de julho de 1823, num festejo enorme que ainda hoje é o principal feriado cívico na Bahia. As quatro datas baianas passaram por trajetórias bem distintas nos anos pós-independência: 8 de novembro e 7 de janeiro não passaram de festas locais, sem sanção oficial. 
Em 1831, 2 de julho foi reconhecido pelo governo imperial como um feriado nacional a ser comemorado apenas na Bahia, o que na época significava principalmente a cidade de Salvador. Seis anos mais tarde, a assembléia provincial aprovou uma lei que designou 25 de junho feriado na Cachoeira. ${ }^{9}$ As duas medidas reconheceram oficialmente comemoraçóes que já eram bem estabelecidas nos seus respectivos municípios. ${ }^{10} \mathrm{O}$ reconhecimento que Salvador e Cachoeira conseguiram para suas festas devese provavelmente à importância dessas duas cidades, cujas elites tinham o prestígio político necessário para consegui-lo; o requerimento enorme (mais de mil assinaturas) enviado à assembléia legislativa nacional para solicitar a designação do dia 2 de julho como feriado em todo o Brasil indica a importância do apoio popular e da identificação com a localidade para o estabelecimento de feriados (KRAAY, 1999, pp. 276-277).

Em Salvador, os feriados com sanção oficial tiveram destinos bem diferentes nos anos 1830 e 1840, quando as fontes jornalísticas se adensam de maneira que se possa julgar a importância do feriado pelo volume de cobertura na imprensa. Através dessa metodologia, constata-se que Dois de Julho era a primeira festa cívica da época, seguido de longe por Dois de Dezembro e Sete de Setembro. Nem 25 de março nem 3 de maio recebiam muita atenção, enquanto 7 de abril deve ter sido um feriado problemático, dado a sua provável associação aos protestos violentos que acompanharam a abdicação, tanto no Rio de Janeiro quanto em Salvador. ${ }^{11}$ A comemoração da aclamação do Dom Pedro II (23 de julho) não chegou a ter a importância do dia 2 de dezembro (seu aniversário) nos anos 1840 .

Durante os anos 1830 e 1840, os três principais festejos cívicos comemorados em Salvador tinham programas semelhantes: um desfile militar, incluindo a guarnição do Exército e a Guarda Nacional; um Te-déum no catedral; iluminação (decoração) de prédios oficiais (e também particulares); cortejo ao retrato do imperador por autoridades civis, militares e eclesiásticas, e também por cidadãos; vivas coletivas ao dia, ao monarca e às autoridades. À noite, havia espetáculo de gala no teatro, durante o qual cantores profissionais executavam o longo hino nacional e um poeta (geralmente Francisco Moniz Barreto, o melhor da cidade) recitava versos patrióticos. No teatro, o presidente da província costumava liderar a pla- 
téia no cortejo ao retrato imperial e no estímulo por outra rodada de vivas, depois do qual se assistia a um drama ou ópera europeus.

A essas cerimônias oficiais, Dois de Julho, o mais popular dos feriados em Salvador, acrescentavam-se diversos elementos, inclusive uma cerimônia anunciadora da festa, o bando, alguns dias antes, no qual um pregoeiro, acompanhado pelos membros da câmara municipal, uma banda de música e foliōes fantasiados, lia a proclamação convidando os habitantes da cidade para participarem de atividades patróticas legítimas. Dois de Julho tinha seu símbolo particular, o caboclo, uma estátua de um índio, esculpido em 1826, e freqüentemente descrito nos anos seguintes como o "gênio do Brasil." Ele era levado à Lapinha, nos subúrbios da cidade para uma vigília durante a noite primeira de julho. Acompanhado por grande quantidade do povo, a quarnição militar e autoridades, o caboclo foi puxado até o centro do Salvador num desfile que lembrava a ocupação pacífica da cidade em 1823. Iluminações, galas no teatro, recitações de poesia e vivas ao imperador continuavam durante diversas noites. Para os festejos do Dois de Julho, os soteropolitanos levantavam arcos triunfais, e durante os anos 1840, começaram a construir grandes palcos e alegorias ao dia (que eram notados com menos freqüência para Sete de Setembro e Dois de Dezembro).

Todos esses elementos das festas cívicas serviam a diversos fins. Juntavam autoridades civis, militares e eclesiásticas em ceremônias públicas que afirmavam sua centralidade no aparato do estado, e associaram-nas à monarquia e à nação. $\mathrm{O}$ desfile militar, dominado numericamente pela Guarda Nacional, arregimentava pública e visivelmente os cidadãos de uma forma ordeira. Essa era uma obrigação a que os guardas — nem a grande quantidade deles dispensados do serviço ordinário — não podiam faltar e o comandante superior tomou medidas para assegurar que nenhum faltasse ao desfile do dia 7 de setembro de $1841 .{ }^{12}$ A "grande parada" mobilizava efetivos significativos: mais de 1.600 homens no dia 2 de dezembro de 1838 e 2.180 (inclusive 139 músicos) dez anos mais tarde. Em 1843, a Guarda estreou o novo uniforme no Dois de Dezembro e, mesmo no dia 7 de setembro de 1838, a recém-reorganizada Guarda conseguiu apresentar dois batalhões "geralmente bem fardados e luzidos." ${ }^{3}$ A participação 
na grande parada tinha tanta importância que os comandantes disputavam arduamente a precedência nela, e em meados dos anos 1830, a designação de um ou outro batalhão da Guarda para o serviço de guarnição provocava grandes clamores da parte dos que não desfiliariam (KRAAY, 1999, pp. 266267).

O Te-déum normalmente lotava a catedral, e os relatos do rito notavam cuidadosamente a presença de autoridades e representantes da câmara municipal, que normalmente o financiava. A falta de dinheiro obrigou a omissão do Te-déum das comemorações do Dois de Dezembro no início dos anos 1840, suscitando comentário crítico de diversos jornais. ${ }^{14}$ Os sermões que antecediam o Te-déum eram principalmente exortações políticas; no dia 2 de dezembro de 1848, o vigário da freguesia do Pilar pregou que "sem união (...) o Brasil, semelhante a uma nau no meio da tormenta, flutuará sem bússola, sem rumo à mercê das ondas revolucionárias até submergir-se." 15 Em 1839, Daniel Kidder não chegou a ouvir o sermão do Dois de Dezembro, mas soube que "foi proferido com grande entusiasmo e gesticulação e que o orador se referia a quase todas a nações estrangeiras, exceto à herética república dos Estados Unidos. Teve ainda tiradas laudatórias ao presidente da província e ao arcebispo," que todavia caiu no sono devido ao calor abafado no catedral (KIDDER, 1845, v. 2, p. 57).

No cortejo, a elite baiana demonstrava sua lealdade ao imperador através do que o severo vice-cônsul britânico, James Wetherell, considerou o costume "bárbaro" de venerar seu retrato depois do Te-déum. Colocada numa sala do palácio, flanqueada pelo presidente, o arcebispo, e às vezes outras autoridades, a "Augusta Efígie de Sua Majestada" representava sua pessoa. "Centenares de cidadãos de todas as classes" (1838) ou as "mais distintas pessoas da capital, além dos que o dever chama a este respeitoso ato" (1843) "inclinavam-se profundamente perante a imagem, e depois perante as autoridades," enquanto uma banda tocava "árias nacionais." 16 Sem a presença física do monarca, o cortejo ao seu retrato servia aos mesmos fins que o beija-mão na corte (demonstrar fidelidade ao imperador) sem, contudo, significar a possibilidade de suplicar mercês pessoalmente (vide MALERBA, 2000, pp. 184-186).

Os retratos dos imperadores, tão largamente difundidos no Brasil, personalizavam o regime imperial e o faziam mais compreensível para a 
população, além de refletirem as grandes mudanças pelas quais passou a monarquia brasileira (SCHWARCZ, 1999). Quando o governo provincial descobriu que não tinha um retrato atualizado do Dom Pedro I em 1824, um foi logo requisitado; no Rio de Janeiro, o pintor oficial recebeu ordem de fazer "sem perda de tempo" um retrato grande do monarca, vestido do "manto imperial," para a Bahia. Chegou em Salvador pouco antes da comemoração do seu aniversário e da Coroação no dia 12 de outubro. Havia tanto interesse em ver a pintura que o presidente ordenou que fosse exibida durante uma semana, vigiada por uma guarda de honra de 20 cadetes. Segundo $O$ Grito da Razão, a exibição foi tão concorrida que o público não cabia no salão do palácio. ${ }^{17} \mathrm{O}$ desejo de possuir imagens do imperador estendia-se às vilas do recôncavo e do sertão, cujas câmaras municipais as solicitavam e as exibiam com muita pompa. ${ }^{18}$

Além de serem objetos da veneração da elite no cortejo, retratos imperiais eram também exibidos publicamente, geralmente nos palcos ou palacetes construídos com freqüência no Dois de Julho, e mais raramente nos outros feriados. No início de Julho de 1839, "um riquíssimo palanque, onde se vê a Efígie do Augusto Monarca Brasileiro" foi iluminado por três noites no Terreiro de Jesus. No "suntuoso monumento" erigido para o Dois de Julho de 1847 destacou-se o retrato imperial no segundo andar, tendo na mão direita a Constituição. Pinturas alegóricas mostravam os oficiais mortos em combate durante a guerra de 1822 e 1823 sendo levados aos céus por um anjo e na inscrição se lia: "Quem morre pela pátria, excelsa glória/adquire no templo da memória." Um jardim artificial com dois chafarizes cercava o monumento. ${ }^{19}$ No aniversário do imperador em 1839, Daniel Kidder visitou o Passeio Público, onde viu:

Um pavilhão em estilo de templo grego. À frente dessa armação, sustentado pelas colunas principais, colocaram um grande retrato de Sua Majestade que naquele dia completava 14 anos. Nos salóes desse palacete havia bandas de música cercadas por nomerosas senhoras e pelos dignitários da província. O retrato do imperador permaneceu coberto por uma cortina até o momento em que o presidente, chegando, puxou o docel e ergueu repetidas vivas à Sua Majestade, à Família Imperial, à nação brasileira e ao povo da Bahia, vivas essas que eram seguidas de ruidosas aclamaçôes do povo enquanto que 
milhares de rojōes riscavam o firmamento num ruidoso pipoquear (KIDDER, 1845, v. 2, p. 61).

Tais espetáculos custavam caro. Em 1848, o pavilhão do Dois de Julho custou 14:000\$, e o Correio Mercantil noticiou que "a assembléia acaba de conceder loterias" para saldar a dívida decorrente da efêmera arquitetura patriótica. ${ }^{20}$

Como se depreende da descrição de Kidder, uma parte integral das ceremônias eram as vivas nas quais as autoridades lideravam o povo em gritos de lealdade. Jornalistas prestavam muita atenção a esse rito. A falta de aplausos ou saudações entusiasmadas por parte do povo na praça (ou pela platéia no teatro) eram indicadores políticos importantes. ${ }^{21}$ Em 1843, $O$ Commercio julgou a omissão do viva ao Dois de Julho uma "censuravel falta" que demonstrava o desprezo do presidente para com a população baiana. A "tormenta de vivas" ao presidente pelas 800 pessoas "de todas as classes" no teatro no dia 2 de julho de 1840 não foi, segundo o Correio Mercantil, "baixa adulação," mas um verdadeiro indício do apoio à sua administração, que fora recentemente criticada no parlamento. Em 1850, O Século noticiou que "cidadãos" se negaram a responder ao viva do comandante das armas à Sua Majestade, o que o jornal considerou "muito significativo", pois demonstrava que a administração provincial, impopular, solapava o apoio à monarquia. ${ }^{22}$

A iluminação noturna de prédios públicos e residências particulares lembrava a todos que eram dias especiais, e faziam da rua um espaço social respeitável. Numa época em que a iluminação pública era muito precária, senão inexistente, tais iluminações tinham mais impacto do que suporíamos hoje. As 1.900 velas no caro palacete do Dois de Julho de 1848 deviam ter sido um grande espetáculo (além de um grande perigo de fogo). ${ }^{23}$ A luz fez com que as ruas fossem mais seguras à noite, e grandes multidões se aglomeravam depois do toque de recolher para apreciar os monumentos e, especialmente no Dois de Julho, assistir às recitações de poesia patriótica e à música patriótica. A multidão incluía "copiosos grupos de senhoras, e homens desfrutando o belo espetáculo" em 1840 e "pessoas de todas as classes" em 1849, muitos dos quais normalmente não saíam da casa depois do anoitecer. ${ }^{24}$ 
Nos espetáculos de gala no teatro, aos quais assistia "a gente mais grade da província, a mais brilhante mocidade baiana" (1849) ou "um numeroso e lusido ajuntamento" (1841), ${ }^{25}$ havia mais uma rodada de vivas quando o retrato imperial era desvelado no início do espetáculo. Na documentação analisada, identifiquei apenas uma referência à exibição de uma peça diretamente relacionada à data comemorada, um drama intitulado $A$ guerra da Bahia, ou a sedução frustrada, representado no dia 2 de julho de $1824 .{ }^{26}$ Normalmente, os espetáculos eram estréias de obras ou dramas europeus. Em 1849, o crítico teatral do Correio Mercantil observou diplomaticamente que Kean, de Alexandre Dumas, seria repetida no dia 4 de Julho, e esperou que então seria "melhor desempenhada," enquanto a produção de 1848 "não foi boa." 27

Tais comemorações oficiais fazem parte do processo cultural da construção do estado e da nação (vide CORRIGAN e SAYER, 1985). A ordem do dia nessas festas cívicas era lealdade ao Brasil, ao imperador e às autoridades. Através desses espetáculos e da sua repetição, o "Estado" procurava constituir os cidadãos brasileiros e inculcar a lealdade na população. O "Estado," claro, não era uma entidade uniforme ou homogênea, ainda mais nas primeiras décadas após a independência; ao contrário, ele estava dividido em complexas facções políticas que podem ser vislumbradas nas festas cívicas.

\section{A política da elite nas festas cívicas}

Enquanto as lições das festas cívicas parecem suficientemente claras — unidade, ordem, lealdade ao Brasil e ao imperador - a política inevitavelmente intrometia-se nas comemorações, como já foi sugerido pelas reportagens sobre o grau de entusiasmo nos vivas. A ênfase constante sobre a necessidade de unidade no discurso oficial em torno das festas cívicas destaca tanto o fato de que não havia consenso quanto ao significado destas festividades, quanto a falta de unidade brasileira ou baiana, duas identidades que se relacionavam de forma ambígua. Disputas sobre a relação apropriada entre a Bahia e o governo imperial no Rio de Janeiro durante os anos 1820 e 1830 afetavam as festas cívicas e, de fato, o estabelecimento do Dois de Julho como um feriado nacional pode ser interpretado como 
um esforço de igualar a luta pela independência na Bahia ao processo do Rio de Janeiro, simbolicamente garantindo a importância da Bahia no império. A partir dos anos 1840, o conflito político-partidário começou a se fazer presente nas festas cívicas.

As divisões entre baianos nunca foram mais claras do que no dia 2 de dezembro de 1837. Pouco menos de um mês antes, eclodira a Sabinada em Salvador, uma das muitas revoltas regionais contra a regência, e até março de 1838 a cidade estaria independente. Senhores de engenho do Recôncavo mobilizaram a Guarda Nacional e com a ajuda de forças militares do governo imperial assediavam a cidade. Todavia, tanto o regime da Sabinada quanto as forças legalistas comemoraram o natalício do jovem imperador. Os rebeldes pediram desculpas pelo fato de que suas comemoraçóes não teriam toda a pompa costumeira, porque muitos dos seus soldados recémrecrutados ainda estavam sem uniformes, mas a reportagem do Novo Diário da Bahia sugere uma comemoração bastante respeitável do "glorioso aniversário do natalício do Senhor Dom Pedro II," com salvas de artilharia, cortejo e grandes iluminações, aos quais foi acrescentado o solemne enterro de um soldado morto em combate. As salvas dos navios da Marinha imperial que bloqueavam a cidade se mesclavam às dos rebeldes, dando um ar surreal a esse ritual, segundo Paulo Cesar Souza, mas também demonstrando a durabilidade da monarquia. A Sabinada, que de fato vacilava na sua orientação política entre república e monarquia, acabou proclamando apenas uma independência provisória, a durar até a maioridade do Dom Pedro II, então prevista para $1843 .{ }^{28}$ Depois da derrota sangrenta da Sabinada, as festas cívicas ofereciam um palco para condenaçóes implícitas e explícitas da rebelião e de todos os "traficantes políticos que querem substituir a anarquia à ordem e ao império da Lei." 29 A aclamação da prematura maioridade de Pedro em 1840 e sua Coroação em 1841 receberam ampla cobertura no Correio Mercantil, então jornal oficial, enquanto nos feriados nacionais desses anos destacavam-se vigorosas afirmações de lealdade ao monarca. ${ }^{30}$

No final da década de 1840, iniciou-se uma nova forma de politização das festas cívicas. A consolidação paulatina dos partidos conservador e liberal e o acirramento da rivalidade entre os dois grupos transbordou para 
as comemorações. Dois de Dezembro de 1848 foi o primeiro feriado nacional que seria presidido pelo recém-empossado presidente conservador, Francisco Gonçalves Martins. "Ultrapartidistas” do presidente ameaçaram a Francisco Moniz Barreto, conhecido liberal, e seus amigos o dissuadiram de recitar seu canto ao Dom Pedro II no teatro. ${ }^{31}$ Aparentemente os correligionários do presidente temiam uma repetição do incidente de 2 de julho de 1846 , no qual houve violência no teatro quando um funcionário público, demitido pelo então presidente, leu um poema que aparentemente o insultava; em resposta, o filho do presidente (e seu ajudante) atacou o poeta com um chicote (vide KRAAY, 1999, 280-281). O poema de Barreto, uma fala ao imperador posteriormente publicada em jornais oposicionistas, de fato tinha seus trechos provocantes:

Sé liberal, se queres ser Monarca

Nas frágoas da política opressora

Exalta-se o amor da Liberdade -

Quem te disser que a compressão o abate

Engana-te, Senhor, mente - e te perde

O povo comprimindo

É caudaloso rio represado

Que ou mais tarde, ou mais cedo rompe os diques,

E com mór violência tudo alaga. ${ }^{32}$

Seus amigos provavelmente tinham razão em fazer Barreto desistir de desafiar publicamente Francisco Gonçalves Martins. Além de divulgar o caso e de publicar o poema, $O$ Século condenou as comemorações desse ano e o presidente que, "abusando do nome do Imperador, aterra, persegue, e ameaça ao povo, a quem ele quer impor uma política que ele tanto detesta." Para o povo, não havia júbilo no feriado, porque temiam o recrutamento forçado, enquanto o presidente, rodeado por seus íntimos, não se dignou de assistir às salvas e a Guarda Nacional, demoralizada, teve que ser conduzida pela polícia durante a grande parada. ${ }^{33}$

Antes do Dois de Julho seguinte, o Correio Mercantil, fervoroso partidário da administração, apelou aos baianos para que ignorarassem os "malintencionados" que pretendiam fazer política no festejo. Sua reportagem sugere um festejo rotineiro, mas um outro jornal lamentou que, apesar do 
Dois de Julho ter sido comemorado "com a mesma pompa," faltava-lhe a "influência" dos anos anteriores por causa dos esforços de politicizar o festejo. ${ }^{34}$ Em 1850, O Século aproveitou-se dos principais feriados para continuar seus ataques ao presidente e à administração saquarema (conservadora), tanto nos editoriais quanto nas reportagens sobre as comemoraçôes. Não havia nada de moderado no tom desse jornal: o "júbilo oficial” no dia 2 de julho foi "bem pungente"; 7 de setembro foi "o elogio fúnebre de uma independência, que, apesar de ter sido conquistada à custa do sangue brasileiro, é hoje uma mentira, um fantasma." ${ }^{35}$

Enfim, até meados do século, a luta dentro da classe política para o controle do ritual cívico virou uma parte importante da política provincial. Não era, na verdade, novidade, mas a proliferação de jornais disponíveis nas décadas de 1830 e 1840 possibilita uma análise mais profunda desses conflitos. Nas primeiras comemoraçóes cívicas baianas, o papel dos poderosos, principalmente senhores de engenho, foi fundamental, como fora importante o papel dos comerciantes fluminenses nas comemorações da corte joanina (MALERBA, 2000, pp. 257-258). O primeiro aniversário da Batalha de Pirajá foi maculado por uma briga sobre precedência entre o futuro Visconde de Pirajá e alguns outros oficiais do Exército. Pirajá tentou impedir que eles nomeassem uma comissão para organizar a festa porque ele "não deixaria a outros o solemnisarem açōes meritórias." Em 1825, Inácio Acciavoli, poderoso senhor-de-engenho na Ilha de Itaparica, financiou toda a comemoração do dia 7 de janeiro. ${ }^{36}$ Em 1830, Pirajá declarou que "tive o prazer de dicar [sic] ao melhor dos soberanos meo Augusto Amo no sempre memoravel Dia Dois" de Dezembro uma comemoração do quinto aniversário do jovem herdeiro ao trono. A cerimônia, todavia, foi prejudicada por um sargento acusado de chicotear uma cigana por nome de Umbelina Maria Roza. Depois que ela reclamou em altas vozes, o Visconde mandou prender o soldado por ter faltado "o decoro devido à Efígie de Sua Majestade, ao público que assistia e a mim que festejava." O sargento justificou-se dizendo que apenas ameaçara a mulher com o chicote quando ele a mandara voltar para casa, uma versão que ela posteriormente confirmou. ${ }^{37} \mathrm{~A}$ violência não devia ser usada perante o retrato imperial, mas Pirajá certamente teria aprovado a expulsão da cigana se fosse feita de maneira mais discreta. 
A retórica estridente em torno das comemorações cívicas de 1848 a 1850 e os esforços da Sabinada para se apropriar das comecorações do Dois de Dezembro demonstram um aspecto importante nesses feriados: já eram tão importantes para a classe política e a alta sociedade que não podiam ser ignorados nem deixados nas mãos dos inimigos. Contudo, os "festejos oficiais" procuravam difundir uma mensagem homogênea e clara à população: lealdade ao imperador, submissão às autoridades, identificação com o Brasil e com o regime imperial. Quando realizadas com êxito, apresentaram a imagem de uma sociedade hierárquica e ordeira. Sua repetição visava criar uma população de brasileiros, cidadãos do império. A presença explícita das divisões políticas nas festas cívicas sugere que tiveram êxito em moldar a arena política e demarcar os limites do discurso político. Nesse sentido, serviam para criar a nação brasileira, nação no sentido antigo de comunidade política, que todavia ainda excluía a muitos. Como é claro no caso de Umbelina, a população inteira não integrava a nação nem gozava dos foros de cidadão. Sua expulsão, de fato, coloca a questão do significado dos ritos cívicos para os homens e mulheres que neles participavam ou simplesmente lhes assistiam.

\section{A política popular nos ritos cívicos}

Como observou E.J. Hobsbawm há mais de uma década, historiadores "sabem muito pouco sobre o que passava (...) na cabeça dos homens e mulheres, relativamente inarticulados, para falar com alguma segurança sobre seu pensamento para com as nacionalidades e os estados-naçóes que reclamavam sua lealdade." Raramente podemos saber, continua, "o que esses consumidores desejavam quando compravam a coleção de bens avulsas apresentadas pelos vendedores da política nacional" (HOBSBAWM, 1990, pp. 78-79). A metáfora de marketing empregada pelo historiador inglês é muito própria para o caso brasileiro, porque os baianos podiam literalmente comprar a parafernália do patriotismo. Em 1830, a Tipographia Viuva Serva \& Filhos anunciou a venda de dois "retratos de Sua Majestade Imperial, que chegaram ultimamente de Paris, e são estampadas com a maior perfeição." O segundo representava Dom Pedro I em busto, segurando a espada "em sinal de firmeza, e unindo ao peito a constituição, em significação de 
ter dado espontaneamente e voluntariamente a seus Povos um Novo Pacto Social." 38 Para os que não podiam pagar o preço, razoavelmente alto, de $2 \$ 550$, a Gazeta da Bahia prometeu reproduzir o busto em seu número especial no dia 2 de julho. Em 1839, a Aurora da Bahia anunciou que daria a todos os seus compatriotas, "sem distinção de pessoa, ou classe," "um folheto com o pomposo título de 'O 2 de Dezembro de 1839.'” O panfleto incluiria "o retrato fiel do Nosso Adorado Jovem Monarca o Sr. D. Pedro 2."39

Como foi consumida ou usada tal iconografia monárquica é difícil de saber, mas os principais feriados em Salvador eram populares, pelo menos no sentido de atraírem um grande público. Relatos jornalísticos do Dois de Julho e Dois de Dezembro nunca deixavam de comentar que quantidades impressionantes de pessoas se aglomeravam na cidade para assistir aos ritos. Os "milhares que se aglomeravam" no Passeio Público em 1839, segundo Kidder, incluíam "o guerreiro e o civil, o comendador, o milionário e o escravo, todos unidos pelo mesmo regozijo" (KIDDER, 1845, v.2, p.59). As multidões não se reuniam indiscriminadamente. Os destinos diferentes dos feriados nacionais em Salvador (a importância do Dois de Julho, seguido por Dois de Dezembro e Sete de Setembro) sugerem que os baianos eram consumidores exigentes das festas cívicas. Um contemporâneo, Antônio Carlos Ribeiro de Andrada Machado e Silva, explicou isso da seguinte maneira: "Não há patriotismo sem provincialismo; não concebo que haja amor para um objeto abstrato; concebo bem que haja bairrismo e provincialismo, e que daqui se chegue ao patriotismo." ${ }^{40}$ O Dois de Julho devia sua popularidade à sua associação à localidade (Salvador e o Recôncavo); a guerra foi uma experiência compartilhada pelos baianos (ou seus pais). Sua compreensão do Brasil foi profundamente afetada pela luta e pela mobilização popular requerida por ela. Dos outros dois principais feriados nacionais, o Dois de Dezembro foi mais fácil de compreender, pois a comemoração dos aniversários reais era uma tradição colonial, tanto quanto uma identidade como sujeitos do monarca. O Grito do Ipiranga, seja qual for sua importância posterior, era abstrato e remoto demais para que o Sete de Setembro concorresse com êxito com o Dois de Julho e o Dois de Dezembro. De fato, o tom dominante nas reportagens do Sete de Setembro é 
um de desempenho rotineiro de uma obrigação, com a exceção importante do ano de 1841, quando o dia 7 de setembro iniciou uma semana de festejos para comemorar a Coroação do Dom Pedro II, realizada no dia 18 de julho. ${ }^{41}$

O que Dois de Julho e Dois de Dezembro significavam para o povo baiano é dificil de elucidar através dos relatos jornalísticos que raramente se dignam de mencionar a população. Analisando o aniversário do monarca em 1843, o Correio Mercantil sustentou que, para a multidão, "panem et circenses foi sempre a sua divisa," talvez pensando no dia 7 de setembro desse ano, quando o Circo Americano estreou "um novo e variado espetáculo adequado a esse tão Grande Dia." ${ }^{2} 2$ Dois de Julho, é claro, era o mais popular dos feriados nacionais, e $O$ Commercio condenou, nesse mesmo ano, aos que "ciumem de ver o povo, a canalha, como eles o chamão, se divertir folgar e correr as ruas coroado de palmas e flores." ${ }^{43}$ Tanto o desprezo do Correio Mercantil para com o povo quanto a defesa dele por $O$ Commercio destacam que a participação popular em festas cívicas era significativa e que nem sempre se enquadrava no programa oficial.

Comemoraçóes oficiais, cuidadosamente programadas, não preocupavam as autoridades e não há indícios que elas temiam a desordem no Sete de Setembro e no Dois de Dezembro, apesar da aglomeração de grandes multidóes no centro da cidade. Dois de Julho era diferente, já que durante esses dias havia muitos festejos não-oficiais. A vigília noturna na Lapinha (que, segundo um jornal, atraiu 6.000 pessoas em 1848) era preocupante, bem como a proliferação de máscaras e outras fantasias que disfarçavam a identidade dos foliōes. ${ }^{44}$ Ademais, à medida que o Dois de Julho comemorava a expulsão dos portugueses, ele podia provocar a violência contra os lusos, estimulada pela retórica antiportuguesa da imprensa oposicionista. ${ }^{45}$ Depois da Sabinada, o Visconde de Pirajá intentava reduzir o Dois de Julho a seus elementos oficiais em 1838, pois nas festas do ano anterior, patriotas atacaram a um português e o obrigaram a libertar um escravo; ademais, nesse ano, houve "scenas de negros matando brancos." ${ }^{46}$ Em 1831, o cônsul britânico relatou (mas com ceticismo) que se esperava "um levante de negros" no dia 2 de julho, mas os festejos passaram pacificamente nesse ano turbulento. ${ }^{47}$ 
Em jogo estava, é claro, o controle sobre os símbolos do estado e da nação. Eram importantes demais para serem deixados nas mãos de populares, como demonstram as preocupações do juiz de paz de Brotas, uma freguesia suburbana de Salvador. Ao relatar uma batida num candomblé em 1829, ele comentou que tais reuniōes podiam causar "alguma catástrofe como a que no sítio do Engenho Velho, fora do meu Distrito, ia sucedendo: porque houveram bandeirolas, partidos, e vozes de viva o Senhor Dom João, e o Senhor Dom Pedro, que a muito custo se acomodou, e foi tanto o povo que num só dia matou-se um Boi, comeu-se, além do mais, e teve gente de várias cores." ${ }^{48}$ As preocupações do juiz são, de certa forma, curiosas: ele não indica quais desastres resultariam do churrasco festivo e multirracial. Saudar o imperador, tal qual faziam autoridades e povo durante as festas cívicas, estava longe de ser uma catástrofe, a não ser que o juiz se preocupasse em prevenir tais apropriações do ritual cívico pelo povo mestiço. ${ }^{49}$ No Dois de Julho, contudo, foi exatamente isso que aconteceu.

Dois de Julho era a festa cívica baiana mais popular (tanto na época como hoje), e nela houve um processo de apropriação do ritual cívico por parte dos populares. Isso já começara com a valorização da participação popular na luta da independência. Para o patriotismo Dois de Julhista, a independência foi uma conquista popular. Todavia, havia ainda a exclusão de muitos, como demonstra o caboclo. Símbolo principal da festa, ele é uma figura indígena pisando a serpente da tirania (associada aos portugueses) e matando-os com uma lança. O símbolo de um indígena idealizado mas indubitavelmente americano apresentava uma imagem clara do que não eram os brasileiros e os baianos: nem portugueses, nem africanos. Os esforços malogrados do presidente Francisco José de Souza Soares de Andréia (natural de Portugal) que tentou eliminar o caboclo dos festejos em meados da década de 1840 revela o grau de lealdade a esse símbolo (sobre esse episódio, vide KRAAY, 1999, pp. 265-268). Ademais, a comemoração de uma mobilização popular no Dois de Julho e sua popularidade quase instantânea nos anos 1820 sugerem que a identidade cívica veio, pelo menos em parte, de baixo. Essa identidade era estreitamente ligada à política exaltada da época. Versículos e cantos, com freqüência com conotações radicais, proliferavam no Dois de Julho. Em 1833, um viajante francês ouviu 
"um negro atlético" que cantava dos seus amores e do seu patriotismo, inclusive o refrão do hino ao Dois de Julho - "Nunca mais! Nunca mais/O depotismos regerá, regerá nossas ações” — texto com claro significado político dado o sentido amplo de "despotismo," qualquer ato arbitrário das autoridades (DUGRIVEL, 1843, p. 384).

Uma indicação do significado popular do Dois de Julho se encontra num artigo satírico do jornal, A Marmota. Em 1849, ele sugeriu que os baianos convidassem os seus vizinhos portugueses para participarem dos festejos, propondo que patriotas designassem um deles para participar de uma alegoria cultural na primeira noite de julho. Sentado num barril, enfeitado de folhas de pitanga, esse "Fragoso" seria levado à Lapinha, onde seria recebido por uma "commissão de crioulas" e o povo, que cantariam um novo hino patriótico à unidade. Seu refrão destacava os elementos festivos do Dois de Julho:

Ferva a patusca

Haja função,

O dia é grande

Viva a União.

Alguns dos seus versículos se referiam às mudanças culturais pelos quais os imigrantes portugueses viravam brasileiros:

Já não há mais Portugueses

É tudo uma gente só

Eles já comem bananas

Já se criāo com bobó

(...)

Eles aqui vão casando

Vão comendo o carurú

Comem molho de pimenta

Dão seu risco no lundú

(...)

Terá lundú na Lapinha

Dance todo Povo em massa

O dia é próprio, gozemos

Q'a vida é curta $^{50}$ 
Não se sabe se algum imigrante português se sujeitou a esse espetáculo, ${ }^{51}$ mas o hino indica um nacionalismo cultural popular, derivado da cozinha e da dança afro-brasileiras, aqui apropriadas como os símbolos de uma identidade brasileira que excluía aos africanos ("Fragoso" seria recebida por crioulos, não por africanos). O lundu — ritmo precursor da samba - que, segundo John Charles Chasteen, florescia em "situações de mestiçagem," era ainda considerado risqué pela elite brasileira (1996, pp. 3536).

A única, mas muito significativa, grande reclamação sobre a participação popular registrada durante outras festas cívicas veio no final da cobertura ampla que o Correio Mercantil deu aos festejos da Coroação em 1841, na qual critica a participação africana neles. Segundo o jornal, as "belas festas" foram maculadas pelos "tumultuosos e numerosos batuques de africanos (...) de dia, e às vezes até alta noite.” Tantos batuques foram realizados que pareciam ser "parte integrante do programa das festas" e um vistitante estrangeiro podia enganar-se que Salvador fosse "uma povoação africana." Não foram poucos os que reclamaram disso ao redator, principalmente no dia 10 de setembro quando o fogo de artifício no Campo Grande teve que enfrentar a concorrência de um batuque, com nada menos de 500 pessoas, na praça de Piedade. ${ }^{52}$ Qual ligação tinham os batuques com os festejos da Coroação é difícil de estabelecer; eram comuns nos domingos e nos outros feriados, e é possível que os africanos simplesmente aproveitassem do feriadão em honra do imperador para manter sua autonomia cultural. Por outro lado, o tamanho do batuque e sua coincidência com a comemoração do império podem indicar uma compreensão africana da monarquia brasileira que o Correio Mercantil certamente não aceitava e talvez nem tinha condições de entender. Diversos estudiosos têm apontado a viva tradição monárquica de liderança africana que se manifestava em candomblés, congadas, quilombos e "reinados negros" no Brasil. ${ }^{53}$ À luz disso, o império brasileiro e suas comemorações não eram estranhas aos africanos que, no caso do batuque da Praça da Piedade, talvez estivessem também comemorando a Coroação do monarca brasileiro. O que é claro, todavia, é que o Correio Mercantil não admitia lugar nenhum para a cultura africana nos festejos cívicos brasileiros. 


\section{Conclusão}

Não é fácil perceber exatamente o que se celebrava nas festas cívicas da época remota do início do século XIX. É claro que o estado imperial tinha grande interesse em difundir uma imagem conveniente do monarca e do estado; havia um projeto de festas cívicas que visava representar a sociedade brasileira como algo ordeira, ordenada hierarquicamente em torno dos símbolos monárquicos. Os esforços dos membros da elite baiana para se associarem aos símbolos do império demonstram a importância deles. O Visconde de Pirajá festejou o aniversário do Dom Pedro II antes mesmo que fosse proclamado feriado nacional e Francisco Moniz Barreto intentou desafiar ao Presidente Francisco Gonçalves Martins no Dois de Dezembro, enquanto o presidente e seus partidiários planejavam uma comemoração ordeira. $\mathrm{O}$ projeto monárquico-imperial era facilitado pela longa tradição colonial de comemorar a família real.

$\mathrm{Na}$ Bahia (e em outras províncias) esse projeto chocava-se com a bemestabelecida identidade local; para muitos baianos, a Bahia era a sua pátria e o Brasil era algo distante ou remoto. Dois de Julho, a maior festa cívica baiana, reforçava a lealdade à pátria (Bahia) mas à medida que apresentava uma interpretação popular da independência brasileira, também negociava simbolicamente a integração da Bahia à "comunidade imaginada" maior do Brasil (ANDERSON, 1991). Essa ambigüidade do Dois de Julho uma festa local que aspirava tornar nacional sua interpretação popular da independência - é essencial para compreender o festejo. Dois de Julho e o aniversário da Batalha de Pirajá se prestavam facilmente a uma interpretação popular da fundação do Brasil, por serem comemorações de episódios que marcaram as vidas dos muitos que participaram da luta pela independência na Bahia. Para eles, a independência fora conquistada por eles mesmos; a nação, fosse qual fosse a compreensão que tinham dela, foi sua própria vitória. Daí a importância do Dois de Julho: ele sustentava que a independência foi uma conquista popular e não uma dádiva do Dom Pedro I nas margens do Ipiranga.

Todavia, não se deve justapor de forma ingênua interpretações populares e elitistas da independência ou impor-lhes uma unidade que inexistia. 
É impossivel saber, por exemplo, se José Barata de Almeida teria apreciado os batuques de setembro de 1841 ou a cultura popular afro-brasileira saudada por A Marmota, mas ele compartilhava com esse jornal satírico uma visão da nação na qual esta era composta das classes populares nãobrancas. Dessa forma, ele implicitamente criticava a elite que se esforçava para manter o controle sobre as festas cívicas e que tentava definir a nação de uma forma estreita. Contudo, essa visão popular da fundação da nação brasileira excluía muitos de seus integrantes. Nem portugueses, nem africanos integravam a comunidade política, mas aos poucos a cultura afrobrasileira virou parte de uma identidade brasileira, como sugere o poema sobre os portugueses que viravam brasileiros. Por outro lado, havia quem negasse a própria existência do patriotismo popular, ou pelo menos se preocupava com a proliferação de comemorações não-oficiais. Podia-se negar seu significado político, como tentou o Correio Mercantil quando comentou que pão e circo eram a divisa do povo; podiam reprimir as comemorações de cunho cívico-popular, como tentou o juiz de paz de Brotas, ou mesmo expulsar elementos indesejados do espaço festivo, como fez o sargento que maltratou a Umbelina. Todavia, essas negaçóes podem ser lidas como evidência de um patriotismo popular cuja existência incomodava os seus críticos. Dessa forma, uma análise de festas cívicas demonstra a complexidade e a variedade das possíveis interpretaçôes da independência e da comunidade política, interpretações instáveis e sempre em jogo.

\section{Notas}

${ }^{1}$ A pesquisa foi financiada pela Universidade de Calgary e pelo Social Sciences and Humanities Research Council do Canadá; agradeço a assistência na pesquisa de Sonya Marie Scott e a revisão do texto em português de Jacqueline Hermann. Todos os jornais citados foram publicados em Salvador. Versōes preliminares do artigo foram apresentadas no V Congresso Internacional, BRASA, Recife, 20 jun. 2000, e no Departamento de História, Universidade Federal Fluminense, Niterói, 24 nov. 2000. Agradeço os comentários dos participantes dessas conferências.

${ }^{2}$ A discussão que segue é baseada em duas fontes: a correspondência de "O Consternado", Diário da Bahia, 14 nov. 1835, pp. 3-4; e O Defensor do Povo, 18 nov. 1835, pp. 159-162. O caso é também analisado por MOREL (2001, pp. 300-316).

${ }^{3}$ Vice-Cônsul ao Ministro Plenipotenciário, Salvador, 6 nov. 1837, Grã Bretanha, Public Record Office, Foreign Office 13, v. 139, fol. 115r-v. O dia, de fato, não passou tranqüi- 
lamente em 1837, porque a Sabinada eclodiu em Salvador no dia 7 de novembro, e não há notícias de qualquer festa patriótica no dia seguinte.

4 "Dia 8 de Novembro," O Século, 9 nov. 1850, p. 2.

${ }^{5}$ Felisberto Caldeira Brant Pontes a Luiz José Carvalho e Mello, Londres, 1 out. 1824, em BRASIL, MINISTÉRIO DAS RELAÇÕES EXTERIORES (1922-1925, v. 2, p. 128). Vide também COSTA (2000, pp. 94-96).

${ }^{6}$ Vide SCHWARTZ (1987); KRAAY (1998); E. SILVA (1993); MOREL (2001).

7 Lei, 9 set. 1826, Coleção das Leis do Brasil. Sobre o aditamento de 3 de Maio, vide o curto debate nos Anais da Câmara dos Deputados (1826), v. 2, p. 36; v. 3, pp. 262-265; a tramitação do projeto no senado pode ser seguida nos Anais do Senado (1826), v. 1, p. 85; v. 2, pp. 100-102; v. 3, pp. 14-16, 122-129. Vide também LYRA (1995).

${ }^{8}$ Decreto, 25 out. 1831; Decreto 146, 26 ago. 1840; Decreto 501, 19 ago. 1848, Coleção das Leis do Brasil.

${ }^{9}$ Resolução, 12 ago. 1831, Coleção das Leis do Brasil; Lei 43, 13 mar. 1837, Coleção das leis e Resoluçôes da Bahia.

${ }^{10}$ Sobre as primeiras comemoraçôes do 2 de Julho, vide KRAAY (1999, pp. 260-261) e MARTINEZ (2000, pp. 69-78). As primeiras referências às comemoraçôes do 25 de Junho se encontram em Presidente a Câmara de Cachoeira, Salvador, 18 mai. 1830, Gazeta da Bahia, 19 jun. 1830; e Nova Sentinella da Liberdade, 24 jul. 1831, pp. 143-146, que traz uma descrição da festa.

${ }^{11}$ Todavia, em 1839, 7 de abril foi "solenisado (...) com todas as demonstrações do público regosijo," Correio Mercantil, 9 abr. 1839, p. 1.

${ }^{12}$ Comandante Superior Interino ao Presidente, Salvador, 29 jul. 1841, Arquivo Público do Estado da Bahia, SACP, m. 3545.

${ }^{13}$ Correio Mercantil, 4 dez. 1838, p. 1; “Mappa da Força em Grande Parada,” 2 dez. 1848, Arquivo Nacional, SPE, IG1, m. 119, fol. 376; Correio Mercantil, 5 dez. 1843, p. 1; 10 set. 1838 , p. 1.

${ }^{14}$ Correio Mercantil, 4 dez. 1838, p. 1; 4 dez. 1841, p. 1; O Mercantil, 4 dez. 1845, p. 1.

${ }^{15}$ O Noticiador Catholico, 9 dez. 1848, p. 227.

${ }^{16}$ Correio Mercantil, 4 dez. 1838, p. 1; 5 dez. 1843, p. 1; WETHERELL (1860, pp. 58-59).

${ }^{17}$ Governo Provisório ao Ministro do Império, Salvador, 24 jan. 1824, in BRASIL, ARQUIVO NACIONAL (1973, p. 81); O Grito da Razão, 14 out. 1824, p. 1.

${ }^{18}$ Câmara ao Imperador, Vila da Barra, 13 mar. 1826, Arquivo Nacional, IJJ9, m. 605; Silva (1825).

${ }^{19}$ Correio Mercantil, 4 jul. 1839, p. 4; 5 jul. 1847, p. 1.

${ }^{20}$ Correio Mercantil, 7 jul. 1848, p. 2.

${ }^{21}$ A amplitude desse espaço político das festas cívicas ainda merece ser estudada. A historiografia reconhece a importância do teatro na política da corte (MALERBA, 2000, pp. 96-100; MAMMI, 2001, pp. 48-49) mas na Bahia o espaço festivo-político estendia-se até as praças da cidade, com a presença de autoridades. Vide também I. SOUZA (1998). 
${ }^{22}$ O Commercio, 5 jul. 1843, p. 2; Correio Mercantil, 6 jul. 1840, p. 1; O Século, 10 set. 1850 , p. 1.

${ }^{23}$ Correio Mercantil, 7 jul. 1848, p. 2.

${ }^{24}$ Correio Mercantil, 6 jul. 1840, p. 1; A Marmota, 4 jul. 1849, p. 2. Vide também KIDDER (1845, v. 2, pp. 59-60).

${ }^{25}$ A Marmota, 4 jul. 1849, p. 2; Correio Mercantil, 4 dez. 1841, p. 1.

${ }^{26}$ Grito da Razão, 6 jul. 1824, p. 1.

${ }^{27}$ A. Ronzi, "Chronica Theatral," Correio Mercantil, 7 jul. 1849, p. 1; Correio Mercantil, 7 jul. 1848, p. 2.

${ }^{28}$ Novo Diario da Bahia, 6 dez. 1837, p. 1; P. SOUZA (1987, p. 72). Sobre a Sabinada, vide também Kraay (1992).

${ }^{29}$ Correio Mercantil, 4 dez. 1838, p. 2; vide também o número de 7 set. 1838, p. 1.

${ }^{30}$ Correio Mercantil, 3 jul. 1840, p. 1; 7 set. 1840, p. 1; Manoel Antonio da Silva Serva, "O Dia Sete de Setembro," Correio Mercantil, 7 set. 1840, pp. 1-2.

${ }^{31}$ Correspondência ao redator de Francisco Moniz Barreto, O Fiscal, 11 dez. 1848, p. 1.

32 O Século, 7 dez. 1848, pp. 3-4; O Fiscal, 11 dez. 1848, p. 2.

33 "Como se festejou o dia 2 de Dezembro," O Século, 5 dez. 1848, p. 1.

${ }^{34}$ Correio Mercantil, 18 jun. 1849, p. 2; 4 jul. 1849, p. 2; "Carta do D. Manoel Jarreta (...)," A Marmota, 14 jul. 1849 , p. 1.

35 "O Dous de Julho como passou," O Século, 9 jul. 1850, p. 1; "O Dia Sete de Setembro de 1850 na Bahia," O Século, 10 set. 1850 , p. 1.

${ }^{36}$ I. SILVA (1919-1940, v. 4, p. 100); O Grito da Razão, 15 jan. 1825, pp. 3-4; Antônio de Sousa Lima ao Presidente, Itaparica, 1 jan. 1825, Biblioteca Nacional, SM, II-33, 31, 19.

${ }^{37}$ Visconde de Pirajá ao Presidente, Salvador, 4 dez. 1830; Tenente-Coronel Comandante, Polícia, ao Presidente, 4 dez. 1830, Biblioteca Nacional, SM, I-31, 15, 25, docs. 36-37. 38 "Avisos," Gazeta da Bahia, 19 jun. 1830, p. 4. Para um outro exemplo, vide "Vendas," Gazeta Commercial da Bahia, 21 out. 1836, p. 4.

39 "Ao respeitavel público," Correio Mercantil, 29 nov. 1839, p. 3.

${ }^{40}$ Fala de 6 jul., Anais da Câmara dos Deputados (1839), v. 2, p. 104.

${ }^{41}$ Vide, por exemplo, Correio Mercantil, 10 set. 1838, p. 1; 9 set. 1847, p. 2; O Século, 10 set. 1850, pp. 1-2. Para 1841, vide o Correio Mercantil de 16, 17 e 20 set., e "Communicado," Correio Mercantil, 25 set. 1841, pp. 1-3.

42 "O Dia 2 de Dezembro," Correio Mercantil, 5 dez. 1843, p. 1; "Circo Americano," Correio Mercantil, 5 set. 1843 , p. 3.

${ }^{43} \mathrm{O}$ Commercio, 10 jul. 1843, p. 1.

${ }^{44}$ Vide, por exemplo, a proibição de máscaras, Correio Mercantil, 26 jun. 1841, p. 3; e uma reportagem aliviada que a noite primeira de julho passara tranqüilamente em 1849, 
Correio Mercantil, 5 jul. 1849, p. 1. A estimativa de 6.000 pessoas se encontra em "Dous de Julho de 1848," Correio Mercantil, 5 jul. 1848, p. 1.

${ }^{45}$ Para comentários sobre essa retórica e exemplos dela, vide Grito da Razão, 6 jul. 1824, pp. 1-2; 6 jul. 1825, p. 2; Nova Sentinella da Liberdade, 2 jul. 1831, pp. 88-89; O Democrata, 30 abr. 1836, p. 319; O Guaycurú, 28 jun. 1845, p. 406; O Século, 7 set. 1850, p. 1 ${ }^{46}$ Visconde de Pirajá ao Regent, 28 jun. 1838 (BAHIA, ARCHIVO DO ESTADO, 19371948, v. 4, p. 372).

${ }^{47}$ John Parkinson a John Bidwell, Salvador, 26 jun. 1831 (particular), Grã Bretanha, Public Record Office, Foreign Office 13, v. 88, fol. 119v; Nova Sentinella da Liberdade, 3 jul. 1831, p. 91.

${ }^{48}$ Juiz de Paz ao Presidente, Freguesia de Brotas, 28 ago. 1829, in REIS e SILVA (1989, p. 129).

${ }^{49}$ No seu análise do documento, João José Reis comenta o perigo dos festejos "fora do controle da polícia e à margem das regras e rituais da cultura nacional brasileira," sem contudo notar os aspectos cívicos do festejo (REIS e SILVA, 1989, pp. 40, 44).

${ }^{50}$ A Marmota, 30 jun. 1849, pp. 1-2.

${ }^{51}$ Nem A Marmota nem o Correio Mercantil o mencionaram nas suas descrições dos festejos do Dois de Julho (números de 4 jul. 1849).

52 Correio Mercantil, 30 set. 1841, p. 1. Essa descrição foi analisada por Jocélio Teles dos Santos, que confunde os festejos da Coroação com a comemoração do dia de um santo, o que o leva a uma análise da influência africana na igreja baiana (SANTOS, 1998, pp. 2930). Foi também analisada por João José Reis, que a coloca no contexto da campanha contra manifestaçóes da cultura africana empreendida pelo Correio Mercantil (REIS, 2001, pp. 349-351).

${ }^{53}$ Essa interpretação dos festejos monárquicos é sugerida por Schwarcz (1999, pp. 248, 257) e I. Souza (1998, pp. 230-232). Vide também REIS (1995-1996, pp. 32-33) e ABREU (1999).

\section{Bibliografia}

BAHIA, ARCHIVO DO ESTADO. Publicações do Archivo do Estado da Bahia: a Revolução de 7 de Novembro de 1837 (Sabinada). 5 vols. Salvador: Eschola Typographica Salesiana, 1937-1948.

BARMAN, Roderick J. Brazil: The Forging of a Nation, 1798-1852. Stanford: Stanford University Press, 1988.

BRASIL, ARQUIVO NACIONAL. A Junta Governativa da Bahia e a independência. Rio de Janeiro: Arquivo Nacional, 1973. 
BRASIL, MINISTÉRIO DAS RELAÇŌES EXTERIORES. Archivo Diplomatico da Independencia. 6 vols., Rio de Janeiro: Lith.-Typ. Fluminense, 1922-1925.

CHASTEEN, John Charles. The Prehistory of Samba: Carnival Dancing in Rio de Janeiro, 1840-1917. Journal of Latin American Studies, v. 28, n. 1, 1996, pp. 29-47.

CORRIGAN, Philip e SAYER, Derek. The Great Arch: English State Formation as Cultural Revolution. Londres: Basil Blackwell, 1985.

COSTA, Emília Viotti da. The Brazilian Empire: Myths and Histories. Ed. Revisada. Chapel Hill: University of North Carolina Press, 2000.

DUGRIVEL, C.M.A. Des bords de la Saône à la Baie de San Salvador, ou promenade sentimentale en France et au Brésil. Paris: Ledoyen, 1843.

HOBSBAWM, E.J. Nations and Nationalism since 1780: Programme, Myth, Reality. Cambridge: Cambridge University Press, 1990.

JANCSÓ, István e KANTOR, Iris (orgs.). Festa: cultura e sociabilidade na América portuguesa. 2 vols. São Paulo: EDUSP e Imprensa Oficial, 2001.

KIDDER, Daniel P. Sketches of a Residence and Travels in Brazil, Embracing Historical and Geographical Notes of the Empire and Its Several Provinces. 2 vols. Philadelphia: Sorin \& Ball, 1845.

KRAAY, Hendrik. "As Terrifying as Unexpected": The Bahian Sabinada, 18371838. Hispanic American Historical Review, v. 72, n. 4, 1992, pp. 501-527.

KRAAY, Hendrik. Between Brazil and Bahia: Celebrating Dois de Julho in Nineteenth-Century Salvador. Journal of Latin American Studies, v. 31, n. 2, 1999, pp. 255-286; tradução portuguesa: Entre o Brasil e a Bahia: as comemorações do Dois de Julho em Salvador, século XIX. Afro-Ásia, v. 23, 2000, pp. 49-87.

KRAAY, Hendrik. The Politics of Race in Independence-Era Bahia: The Black Militia Officers of Salavdor, 1790-1840. In: KRAAY, Hendrik (Org.). AfroBrazilian Culture and Politics: Bahia, 1790s-1990s. Armonk: M.E. Sharpe, 1998, pp. 30-56.

LYRA, Maria de Lourdes Viana. Memória da independência: marcos e representaçōes simbólicas. Revista Brasileira de História, v. 15, n. 29, 1995, pp. 173206.

LYRA, Maria de Lourdes Viana. "Pátria do cidadão": a concepção de pátria/nação em Frei Caneca, Revista Brasileira de História, v. 18, n. 36, 1998, pp. 395-420. 
MALERBA, Jurandir. A corte no exílio: civilização e poder no Brasil às vésperas da independência (1808 a 1821). São Paulo: Companhia das Letras, 2000.

MAMMI, Lorenzo. Teatro em música no Brasil monárquico. In JANCSÓ e KANTOR (2001, vol. 1, pp. 37-52).

MARTINEZ, Socorro Targino. 2 de Julho: a festa é história. Salvador: Prefeitura Municipal do Salvador, Secretaria Municipal de Educação e Cultura, Fundação Gregório de Mattos, 2000.

MOREL, Marco. Cipriano Barata na sentinela da liberdade. Salvador: Academia de Letras da Bahia; Assembléia Legislativa do Estado da Bahia, 2001.

PRIORE, Mary del. Festas e utopias no Brasil colonial. São Paulo: Brasiliense, 1994.

REIS, João José. Batuque negro: repressão e permissão na Bahia oitocentista. In JANCSÓ e KANTOR (2001, vol. 1, pp. 339-358).

REIS, João José. Quilombos e revoltas escravas no Brasil. Revista USP, v. 28, 19951996, pp. 14-39.

REIS, João José, e SILVA, Eduardo. Negociação e conflito: a resistência negra no Brasil escravista. São Paulo: Companhia das Letras, 1989.

SANTOS, Jocélio Teles dos. Divertimentos estrondosos: batuques e sambas no século XIX. In: SANSONE, Lívio, e SANTOS, Jocélio Teles dos (orgs.). Ritmos em trânsito: sócio-antropologia da música baiana. São Paulo: Dynamis, 1998, pp. 15-38.

SCHWARCZ, Lilia Moritz. As barbas do imperador: D. Pedro II, um monarca nos trópicos, 2. ed. São Paulo: Companhia das Letras, 1999.

SCHWARTZ, Stuart B. The Formation of a Colonial Identity in Brazil. In: CANNY, Nicholas, e PAGDEN, Anthony (orgs.). Colonial Identity in the Atlantic World, 1500-1800. Princeton: Princeton University Press, 1987, pp. 15-50.

SILVA, Eduardo da. Prince of the People: The Life and Times of a Brazilian Free Man of Colour. Tradução de Moyra Ashford. Londres: Verso, 1993.

SILVA, Francisco Antonio de Andrada e. Exposiçāo da collocação do retrato do Sr. D. Pedro de Alcantara, primeiro imperador do Brasil na casa da muito nobre e leal Villa de São Francisco de Sergipe do Conde (...). Rio de Janeiro: Typ. de Torres, 1825.

SILVA, Ignacio Acioli de Cerqueira e. Memorias historicas e politicas da provincia da Bahia (...), 6 vols. Braz do Amaral (org.). Salvador: Imprensa Official do Estado, 1919-1940. 
SOUZA, Iara Lis Carvalho. Pátria Coroada: o Brasil como corpo político autônomo, 1780-1831. São Paulo: Fundação Editora UNESP, 1998.

SOUZA, Paulo Cesar. A Sabinada: a revolta separatista da Bahia (1837). São Paulo: Brasiliense, 1987.

WETHERELL, James. Brazil: Stray Notes from Bahia, Being Extracts from Letters, \&c., during a Residence of Fifteen Years. HADFIELD, William (Org.). Liverpool: Webb and Hunt, 1860.

\section{Resumo}

Através de uma análise dos ritos civicos na Bahia após a Independência, este artigo examina a maneira pela qual o Estado e a nação foram representados e pensados tanto pela elite quanto pelo povo no espaço festivo que reunia todas as classes sociais. Desta maneira, aborda as grandes questôes sociais e politicas numa época em que uma sociedade recém-saida do regime colonial tentava se representar: raça, cidadania, pertencimento à nação e lealdades locais versus lealdade nacional. $O$ artigo sustenta que havia uma visão popular do Estado que não se enquadrava nas festas oficiais e que perpetuava uma leitura alternativa do significado da Independência. Todavia, aos poucos, as festas civicas contribuiram para of fortalecimento de identidades brasileiras e baianas.

\section{Abstract}

Through an analysis of civic rituals in post-independence Bahia, this article examines the ways in which the state and the nation were represented and understood both by the elite and by the people in a festive space that brought together all social classes. In this way, the article addresses the larger social and political questions that a recentlyindependent society faced as it sought to represent itself publicly: race, citizenship, membership in the nation, and regional versus local loyalties. It argues that there was a popular vision of the state that escaped the script of official civic rituals and that presented an alternative reading of independence's meaning. Nevertheless, civic rituals contributed to the strengthening of both Brazilian and Bahian identities. 